\title{
Sequential Casting Using Multiple Materials: A Bronze Age "Royal Sceptre" from the Halil Rud Valley (Kerman, Iran)
}

\section{Nasir Eskandari, Francois Desset, Lara Maritan, Arnaldo Cherubini \&} Massimo Vidale

To cite this article: Nasir Eskandari, Francois Desset, Lara Maritan, Arnaldo Cherubini \& Massimo Vidale (2019): Sequential Casting Using Multiple Materials: A Bronze Age "Royal Sceptre" from the Halil Rud Valley (Kerman, Iran), Iran, DOI: 10.1080/05786967.2019.1605494

To link to this article: https://doi.org/10.1080/05786967.2019.1605494

曲 Published online: 22 Apr 2019.

Submit your article to this journal $\pi$

山 Article views: 1

View Crossmark data $\nearrow$ 


\title{
Sequential Casting Using Multiple Materials: A Bronze Age "Royal Sceptre" from the Halil Rud Valley (Kerman, Iran)
}

\author{
Nasir Eskandari ${ }^{a}$, Francois Desset ${ }^{b}$, Lara Maritan ${ }^{c}$, Arnaldo Cherubini ${ }^{d_{*}}$ and Massimo Vidale ${ }^{d}$

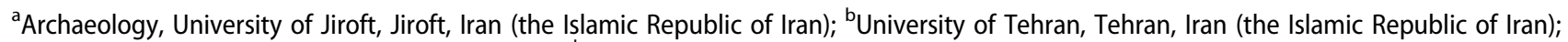 \\ 'Geosciences, University of Padova, Padova, Italy; ${ }^{\mathrm{d} C u l t u r a l ~ H e r i t a g e, ~ U n i v e r s i t y ~ o f ~ P a d o v a, ~ P a d o v a, ~ I t a l y ~}$
}

ABSTRACT

This paper deals with a unique artefact currently on exhibit at the archaeological Museum of Jiroft (Kerman, Iran), a large-sized copper or bronze staff inlaid with shell mosaics of contrasting colours. Unfortunately, as it was confiscated with many other objects by the Iranian security forces from illegal excavators, nothing is known of the whereabouts or context of its discovery. It might be one of the largest copper artefacts ever found in Bronze Age sites of the eastern Iranian Plateau. Because of its form, such a unusually elaborated, costly and visually imposing staff must have performed a highly formal symbolic function, hence the hypothetical label of "royal sceptre" (in quotes) proposed in the title. The authors attempt a reconstruction of the original form and manufacturing sequence of this large artefact, discussing its role in the poorly known landscape of the protohistoric metallurgy of south-eastern Iran.

\section{KEYWORDS}

Bronze sceptre; Halil Rud or Jiroft civilisation; multimaterial lost-wax casting; shell inlays; Iran; Bronze Age

\section{Introduction}

After the lootings in the Halil Rud valley of 2001 (Figure 1), and the original publication of a substantial number of objects recovered from illegal excavators in the Jiroft area, Kerman, Iran, ${ }^{1}$ other selection of artifacts were published in the following decade. ${ }^{2}$ However, a number of important artefacts of the collection of the Museum of Jiroft remain unpublished; many would need proper cleaning and restoration (in particular, those made of copper) and there is no information on their materiality. What is clear is that many beautiful stone and metal objects belonged to the graves of a powerful aristocracy, most probably as rich and powerful as its Sumerian counterpart. Unfortunately, the catastrophic destruction of the Halil Rud cemeteries has been systematic, and unless new systematic investigations will change the picture, we will never know the original aspect of these elite burials, nor reconstruct the involved funerary rituals.

The rescue work carried out by part of the authors on the site of the plundered third millennium BC graveyard of Mahtoutabad, ${ }^{3}$ where in a single disturbed spot the looters left more than 1500 microbeads of gold, turquoise and lapis lazuli, fragments of about 50 different carved chlorite vessels, pieces of copper vases (at least 50, some of which with embossed figurations), broken daggers and an axe $e^{4}$ give only a faint idea of the original richness of part of the destroyed graves of the Halil Rud valley. Equally rich must have been the still unpublished catacomb graves found by Y. Madjidzadeh nearby Qaleh Koutchek (5 km northwest of Konar Sandal south). The microstratigraphic excavation of the single undisturbed grave found at Mahtoutabad (saved only because it was concealed beneath a much larger burial pit that had been completely pilfered) revealed a complex sequence of ritual acts reflecting an extended funerary feast, ${ }^{5}$ a circumstance that renders even more bitter the loss of the richest tombs of the second half of the third millennium BC. This paper focuses on a large copper sceptre at the Jiroft museum (Figures 2 and 3, hypothetical reconstruction in Figure 4), whose origins, like those of many other finds of the same collections, are unknown. This highly symbolic object might have been found in a particularly rich, perhaps "royal" grave, but we cannot exclude, as we shall see, that it came from a different context of deposition.

CONTACT Massimo Vidale mass.vidale@gmail.com 0 Cultural Heritage, University of Padova, complesso del liviano, piazza capitaniato 7, Padova 35139, Italy ${ }^{*}$ Current address: Independent Researcher

${ }^{1}$ Madjidzadeh, Jiroft. The Earliest Oriental Civilization.

${ }^{2}$ Piran and Hesari, Cultural around Halil Roud and Jiroft, the Catalogue of Exhibition of Select Restituted Objects; Piran and Madjidzadeh, Objects from the Jiroft Treasury.

${ }^{3}$ Vidale, "Searching for Mythological Themes on the 'Jiroft' Chlorite Artefacts," 15-58.

${ }^{4}$ Desset and Vidale, "Ongoing Research."

${ }^{5}$ Desset et al., "A Grave of the Halil Rud Valley (Jiroft, Iran, ca. 2400-2200 BC)," 25-60.

(c) 2019 British Institute of Persian Studies 


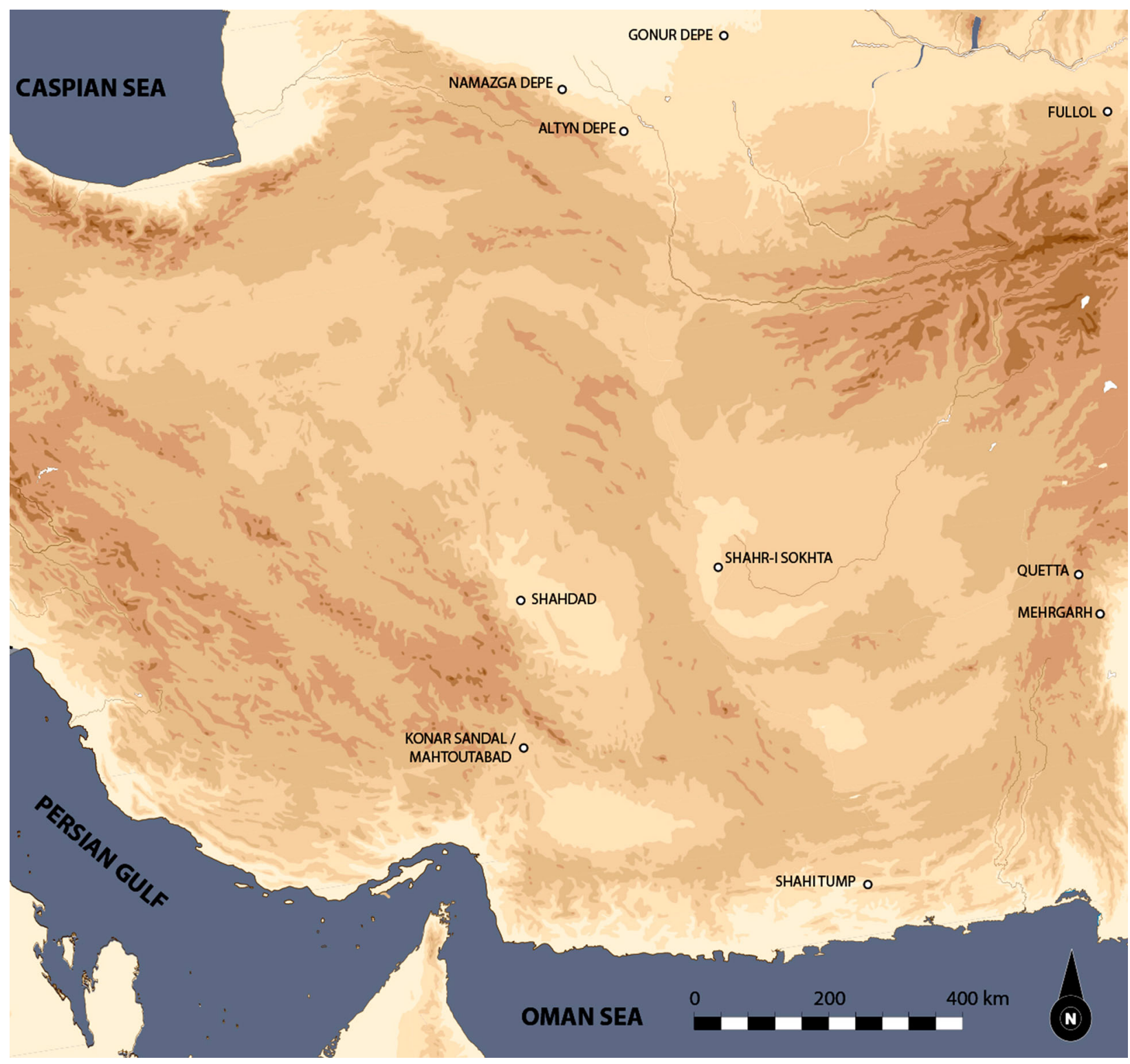

Figure 1. Map of the Chalcolithic and Bronze Age sites mentioned in the text (F. Desset).

\section{Methods of Study}

What follows is mainly due to two days of joint closeup observation of the sceptre in the Jiroft Museum by part of the authors (NE, FD and MV). AC, in collaboration with $\mathrm{MV}$, on the base of the pictures and field notes, created a theoretical but -we believe - reliable reconstruction of the original model of the sceptre (Figure 3). Unfortunately, as we had no permission to take solid samples of the copper/bronze shell, nor of the shell inlays, we had to limit ourselves to carefully detach two minimal chips (respectively, 4 and $2 \mathrm{~mm}$ ) of what looked like the casting core of the object from its wide-open, therefore accessible upper bulb. These fragments were analysed by LM at the Dept. of Geosciences, University of Padova, by thin- sections petrography, scanning electron microscope (SEM) and X-ray powder diffraction (XRPD). Combined with our observations of the surface, the results revealed that the manufacturing technology of the object was a much more complicated issue than we previously had expected.

\section{Description of the Jiroft Sceptre}

The sceptre shows no recent damage or alteration, nor evidence of any conservation treatment. Although many inlays are missing, and their sockets in many points are void, there is neither sign of recently relocated shell pieces nor of modern polymers or glues. It is strongly corroded and entirely covered with a thick layer of thick green copper carbonates. Along the edges 


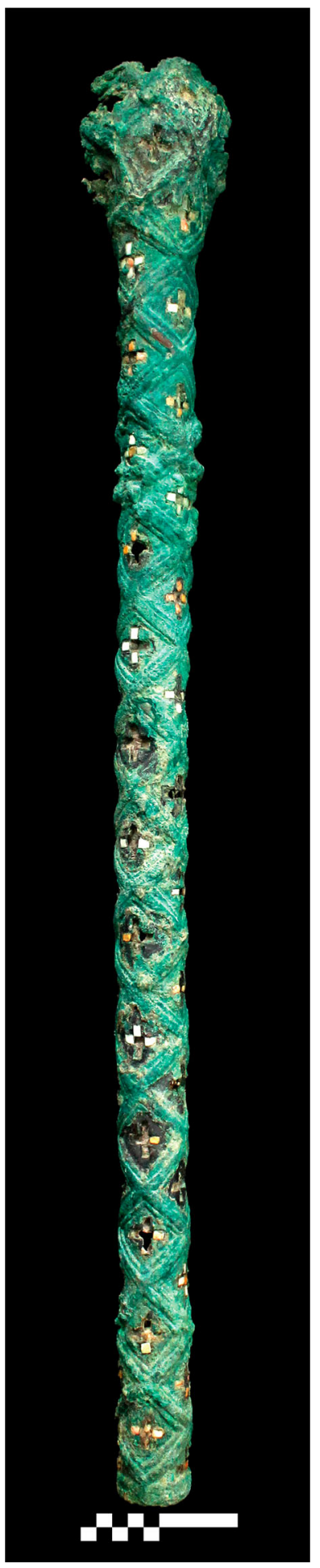

Figure 2. Picture of the staff, in its present state (F. Desset).

of the recesses left by fallen inlays, copper shows a variety of alteration surfaces, from green to pinkish grey to deep purplish black. On the rear of the empty sockets appears a background of altered lead.

At many points, corrosion of copper (or bronze) has caused the surface to swell and create large bulges. Where metal is better preserved, the thickness is quite
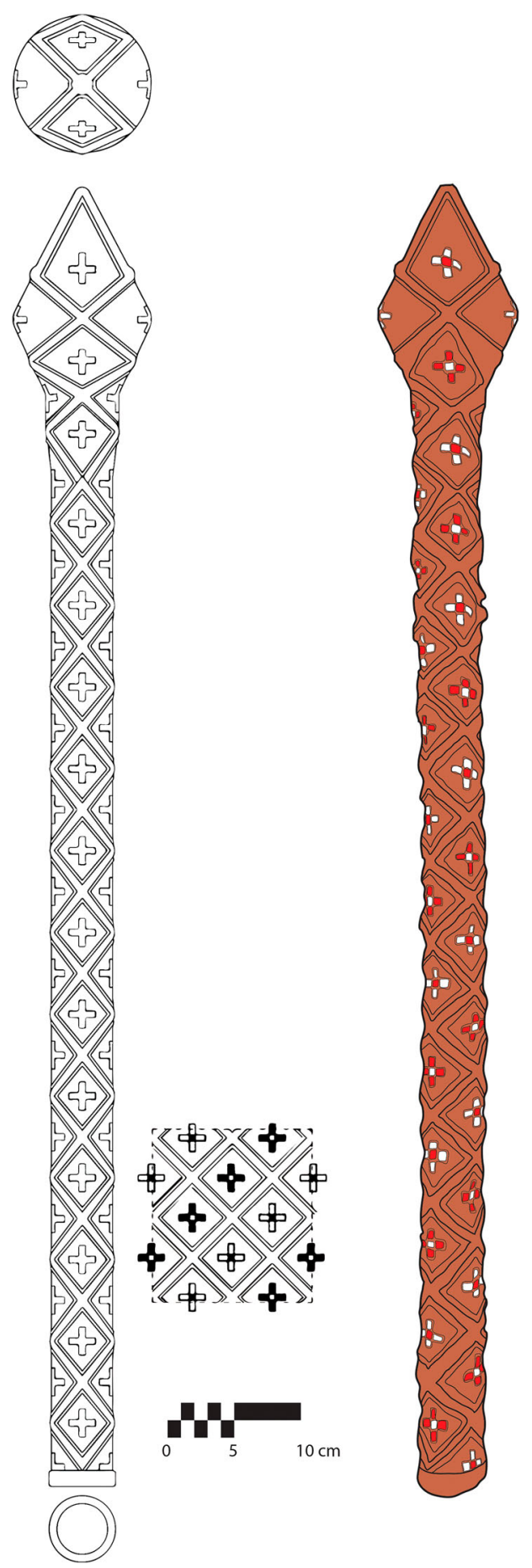

Figure 3. AUTOCAD hypothetical model of the original design of the sceptre (A. Cherubini), with detail of the spiral pattern of the cross-like shell mosaics (left); the colour design at right (F. Desset) combines the model with a design taken from the photograph of Figure 2.

even, about $3.2 \mathrm{~mm}$, both on the handle and bulb. Such uniformity and the apparent absence of bubbles are a sign of a rather efficient casting process. The bulb is broken up and badly warped, with part of the wall, including the top, missing. The swollen edges of the 


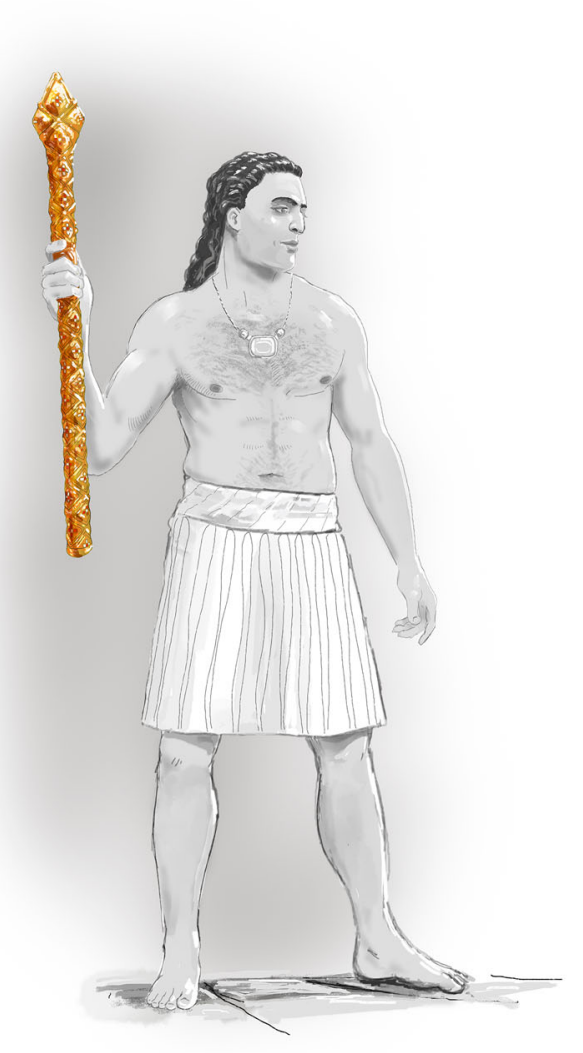

Figure 4. How the object may have looked, if handled as a insignia of power (F. Desset / Nicolas Jamme; https://nj2d20. wixsite.com/nicolasjamme).

fracture are clean cut, suggesting that what is not preserved was not gradually crumbled by corrosion during burial, but rather forcibly deformed and perhaps removed in the past.

In the described state, the sceptre is about $90 \mathrm{~cm}$ long. The original length, with the missing top ("bulb") should have been 5-8 cm longer (reconstruction in Figure 3). The pointed end of the bulb, in the same illustration, results from the projection of the last unmodified orientation of the wall above the maximum expansion. The diameter of the cylindrical lower portion ("handle") is $4.5 \mathrm{~cm}$. It ends, at the base, with a plain band in slight relief, $1.2 \mathrm{~cm}$ high. On the opposite end, the bulb, before breakage, should have been ca $10-12 \mathrm{~cm}$ wide.

The surface of the staff, both on handle and bulb, is entirely covered with series of adjacent vertical squares/ lozenges, each regularly enclosed by three concentric strips in low relief (respectively, from the exterior, 0.35 , $0.58,0.35 \mathrm{~cm}$ wide), forming a single frame. The central strip, besides being larger, is also thicker. The width (or horizontal diagonal) of each square/lozenge, including the width of the two horizontal angles of the threefold frame, covers the entire semi-circumference of the handle.

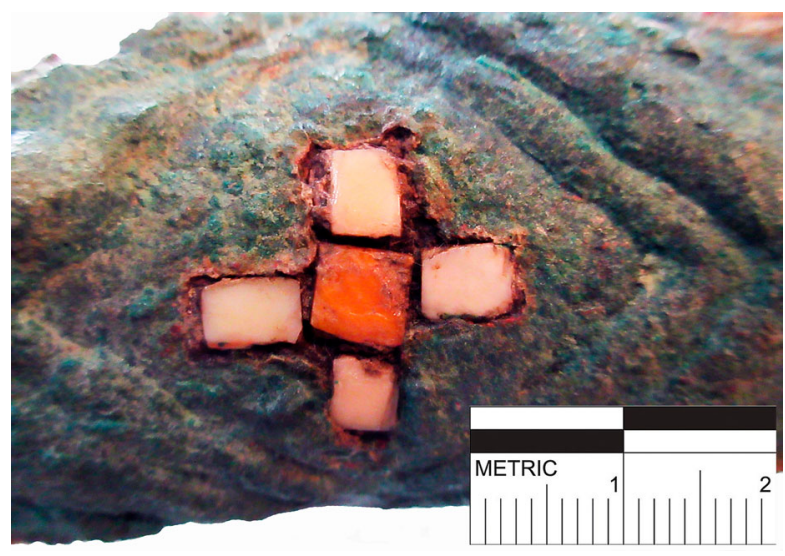

Figure 5. An example of a white mosaic cross with a red core (M. Vidale).

Without considering the curvature of the handle, each square/lozenge would be ideally inscribed in squares $6 \mathrm{~cm}$ wide. The lozenges, however, resulted from the application to the wax model continuous threefold strips of wax, regularly intersecting with the same angles. The series of lozenges that appear vertically on the single views of the sceptre are lightly twisted to the left (compare the picture in Figure 2 with the ideal reconstruction of Figure 3). Also, due to the bulging volume of the upper bulb, this basic geometry, there, is slightly modified.

The space included within the described squares/ lozenges in low relief is flat, but for the cross-like recesses of the inlays. Here are visible the inner cross patterns made of five rectangular/square shell inlays, four for the arms, and one for the centre of the cross. Along the vertical axis of the handle inlays alternate in colour: white crosses with a red centre (Figure 5) are followed by red-armed crosses with a white centre (Figure 6, see
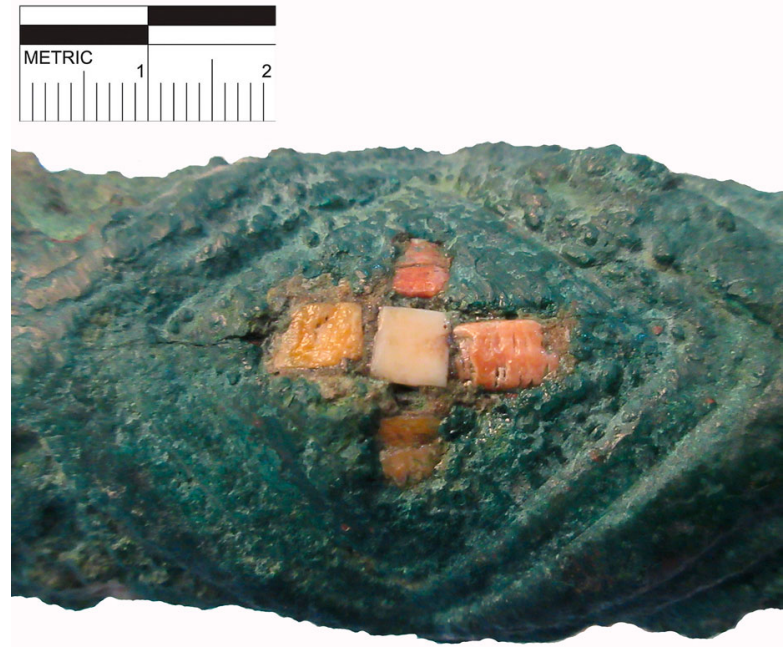

Figure 6. An example of a red mosaic cross with a white core (M. Vidale). 
also the general pattern in Figure 3). Each mosaic cross, from the extremity of one arm to the opposed end, measures on average around $2.1 \mathrm{~cm}$. The average width of the arms, like the sides of the central inlay piece, is ca $0.5 \mathrm{~cm}$.

In our reconstruction of Figure 3, not less than 52 squares/lozenges run along the handle; two half crosses are visible at the base, and six other lozenges on the bulb, for a total of 298 shell inlay pieces originally applied to the sceptre.

\section{An Unusual Casting Core}

The visual inspection of the sceptre makes clear that it was fabricated with a direct lost-wax (cire perdue) casting process. This is not surprising, as the earliest lost-wax copper products so far scientifically reported for Southwest Asia are the impressive finds of the middle chalcolithic hoard of Nahal Mishmar on the west bank of the Dead Sea ${ }^{6}$ hollow casts on solid refractory cores (last quarter of the 5th millennium BC), and the small, solid miniature spoked wheel found at Mehrgarh, less precisely dated to the late period III (ca 4500-3600 BC). ${ }^{7}$ Since the 4th millennium BC, this technique (or "family" of techniques) was widely spread across southern Eurasia.

On the sceptre, we looked carefully for joints, signs left by copper pins or chaplets for securing the outer mould to the inner core or for the negative evidence of ducts for pouring the molten copper during casting and vents for the gases produced in the process, but found none. A film of the original core, later invested by the bronze shell, is still preserved within the cast copper shell, but it presents not a few problems. Along the open inner surface of the bulb there is a very hard, coarse material composed to a large extent by a yellowish-red groundmass, and permeated by copper corrosion products (Figure 7); the most evident inclusions are white or translucent crystalline fragments with sharp angular contours of variable size (from 1 to $10 \mathrm{~mm}$ ) (Figure 8).

Presumably, the same composite, hardened material had been previously removed from the cavity of the bulb. Although we cannot exclude that the bulb was emptied mechanically after its breakage, a probable solution is that lead, molten during or after the copper/ bronze casting process, was let to flow outside through the handle after the bronze had solidified (see below).

Two small fragments of such compact, massive core were sampled and microscopically and mineralogically analysed. Under the polarised-light microscope

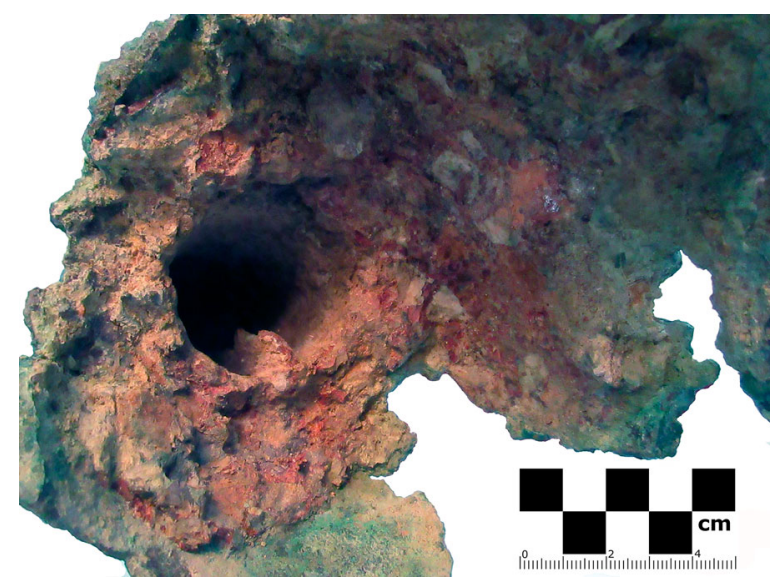

Figure 7. A view of the interior of the broken bulb of the sceptre, showing a rough coat of lead oxides studded with angular quarts flakes of variable size $(1-10 \mathrm{~mm})$. A copper/bronze seepage penetrates vertically from the outer shell into the empty shaft of the handle (M. Vidale).

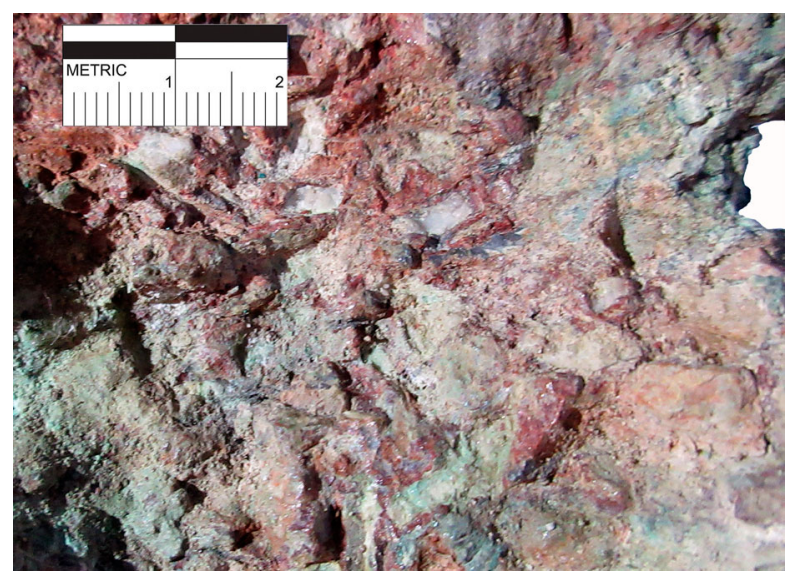

Figure 8. Detail of the lead-oxides and quartz coating observed in the interior of the bulb (M. Vidale).

(Figure 9), the core of the bulb shows quite a peculiar structure, formed by two distinct portions. One is the above mentioned groundmass, which in turn is made of a completely opaque phase (black portion in Figure 9) and a red one, with a sort of micro-layered structure. The other portion (up-right in the same Figure 9) is transparent and shows low relief and low interference colours typical of quartz and feldspars phases.

The analysis of this fragment at SEM, coupled with a EDS micro-analysis, shows that the opaque portions are entirely composed of lead oxides, showing different atomic number (different grey colour in Figure 10(a, b)), the darker grey of which can be attribute also according to the mineralogical analysis to minium, a lead

\footnotetext{
${ }^{6}$ Moorey, "The Chalcolithic Hoard from Nahal Mishmar, Israel, in Context," 171-189; Hansen, "Key Techniques in the Production of Metals in the 6th and 5th Millennia BCE," 136-148.

${ }^{7}$ Thoury et al., "High Spatial Dynamics-Photoluminescence Imaging Reveals the Metallurgy of the Earliest Lost-Wax Cast Object," 13356.
} 


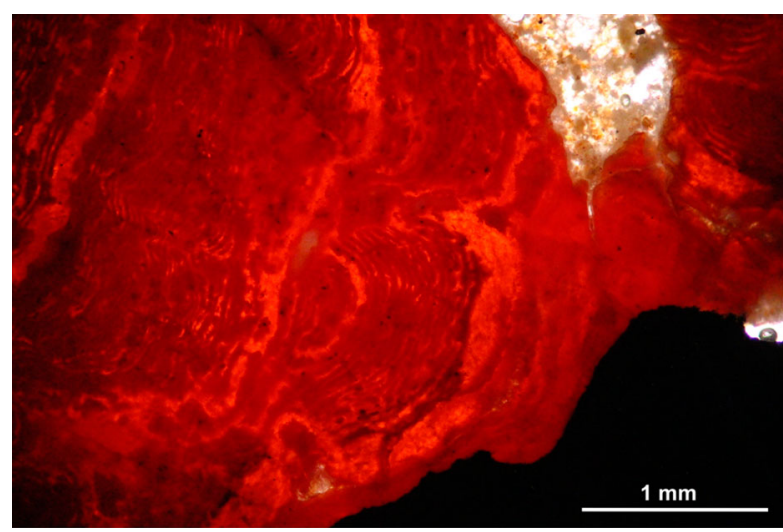

Figure 9. Parallel-polarised light microphotograph of a microfragment taken from the casting core, inner bulb (L. Maritan).

tetroxide $\left(\mathrm{Pb}^{2+} 2 \mathrm{~Pb}^{4+} \mathrm{O}_{4}\right)$ also known as red lead, which derived from the oxidation of molten lead. The structure of this part is clearly layered and show micro-pores in some cases filled by a lead alloy, rich in $\mathrm{W}$. The lighter grey one may correspond to the lead dioxide $\left(\mathrm{Pb}^{4+} \mathrm{O}_{2}\right)$ derived from the oxidation of $\mathrm{Pb}_{3} \mathrm{O}_{4}$. Next to these lead phases, there are also the remains of a possible outer peel of heated clay, where a vitrified clay matrix contain the relicts of grains of quartz and feldspar, partially melted as testified by the smoothed grain boundaries.

Quartz and feldspar fragments are present as very fine inclusions in the sintered interface with the bronze shell; angular macro-crystalline pieces of quartz are easily recognised along the inner surface of the bulb (Figure 8). The presence of angular grains probably coming from a ground intrusive rock in the oxidised lead suggests that this artificial lithic component had been added by the smiths to the molten lead core, perhaps for making the object lighter. The mineralogical analysis by XRPD of the second fragment of this peculiar core indicated that, in addition to quartz, traces of muscovite/illite and zeolite, related to heated clay material and its alteration after burial, also mineral phases related to both lead and copper and their alteration products are found (Figure $10(c, d)$ ). In particular, the presence of amorphous phases, testified by background bump between 30 and $45^{\circ} 2$ Theta in the diffraction pattern (Figure 11) indicate that the clay material underwent sintering. The occurrence of the clay minerals (illite/muscovite) is probably related to contamination by external soil. Zeolite, instead, represent alteration products related to the devitrification of the vitrified clay material. As for the lead phases, while litharge $\left(\mathrm{Pb}^{2+} \mathrm{O}\right)$ can derive by heating lead in casting, hydrocerussite $-\mathrm{Pb}_{3}\left(\mathrm{CO}_{3}\right)_{2}(\mathrm{OH})_{2}$ - formed for alteration of lead ore minerals or lead metal. Similarly, the presence of limited amounts of the sulfosalt tennantite $\left(\mathrm{Cu}_{12} \mathrm{As}_{4} \mathrm{~S}_{13}\right)$ derives from the alteration of an original copper-arsenic alloy.

The inspection of the interior of the handle, at the join with the bulb, shows a central cavity measuring $3-3.5 \mathrm{~cm}$ in diameter (its end, at the base of the bulb, visible in Figure 7). A ridge of copper drained from the wall into a vertical crack of this inner coating (see, again, Figure 7) is a clear evidence of the presence of a fexured core before casting. The material(s) still present as a continuous coat within the handle, like the other metallic parts, could not be sampled. However, while the inner cylindrical cavity of the handle has a distinctive smooth surface, the background of the cross-like sockets, where the inlays are lost, has the distinguishing features of lead. Moreover, in such spots one sees particles distinguished by a bright red colour. Thus, the inner coat of the handle's tunnel-like cavity might contain the same lead observed and analytically recognised within the interior surface of the bulb.

\section{Comparison with Other Complex Castings of the Late Fourth and Late Second Millennium BC}

The so-called "Leopard Weight" found in grave 402 of the prehistoric cemetery of Shahi-Tump ${ }^{8}$ provides a possible comparison. Made of a copper-lead jacket filled with solid lead, it is inlaid with shell geometric pieces. Dated to period IIIa (late 4th-early 3rd millennium BC) of the Makran sequence, it was found in a male grave. It is an ovoid ball (more of $15 \mathrm{~kg}$ in weight) with a limited flat base and an upper handle. It is decorated with white and reddish-orange shell inlays. Its outer, hollow jacket was cast with alloyed copper (in weight $\%, 12.6 \%$ lead, $3.5 \%$ arsenic, $1.3 \%$ antimony) filled with pure lead poured in two or three casting flows. The shell inlaid figuration shows two leopards attacking from rear two ibexes; four highly stylised flies appear in between. The figures have a light grey colour that contrasts with the dark green background of the copper jacket; the light grey material that forms the animals' bodies is hydroxycerussite, from surface alteration of the inner lead core.

We summarise the proposed reconstruction of the casting process. ${ }^{9}$ First a solid clay core was modelled, the decorative scenes are drafted and their contours

\footnotetext{
${ }^{8}$ Mille, Besenval and Bougarit, "Early 'Lost-Wax-Casting' in Baluchistan (Pakistan)," 264-271; Mille, Bougarit and Besenval, "Metallurgical Study of the 'Leopards Weight' from Shahi-Tump (Pakistan)," 237-244; Besenval, "Between East and West," 41-164.

${ }^{9}$ Mille et al., "Metallurgical Study."
} 

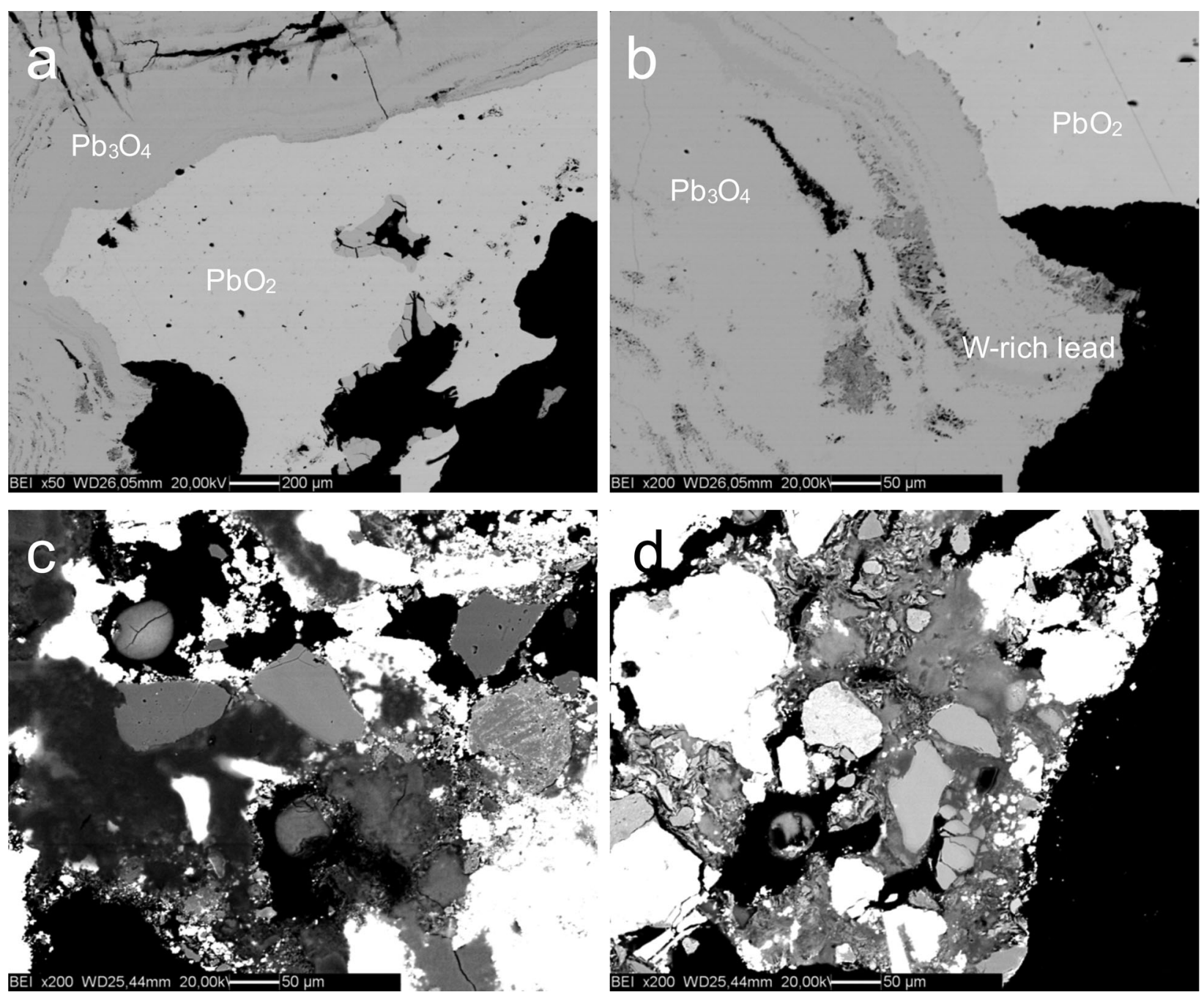

Figure 10. Back-scattered electron images at the SEM of: a-b) Pb oxides with a different oxidation state (different grey colours); $c-d$ ) at the interface between lead and bronze, heated clay material where relicts of quartz and feldspars appear in a vitrified groundmass (L. Maritan).

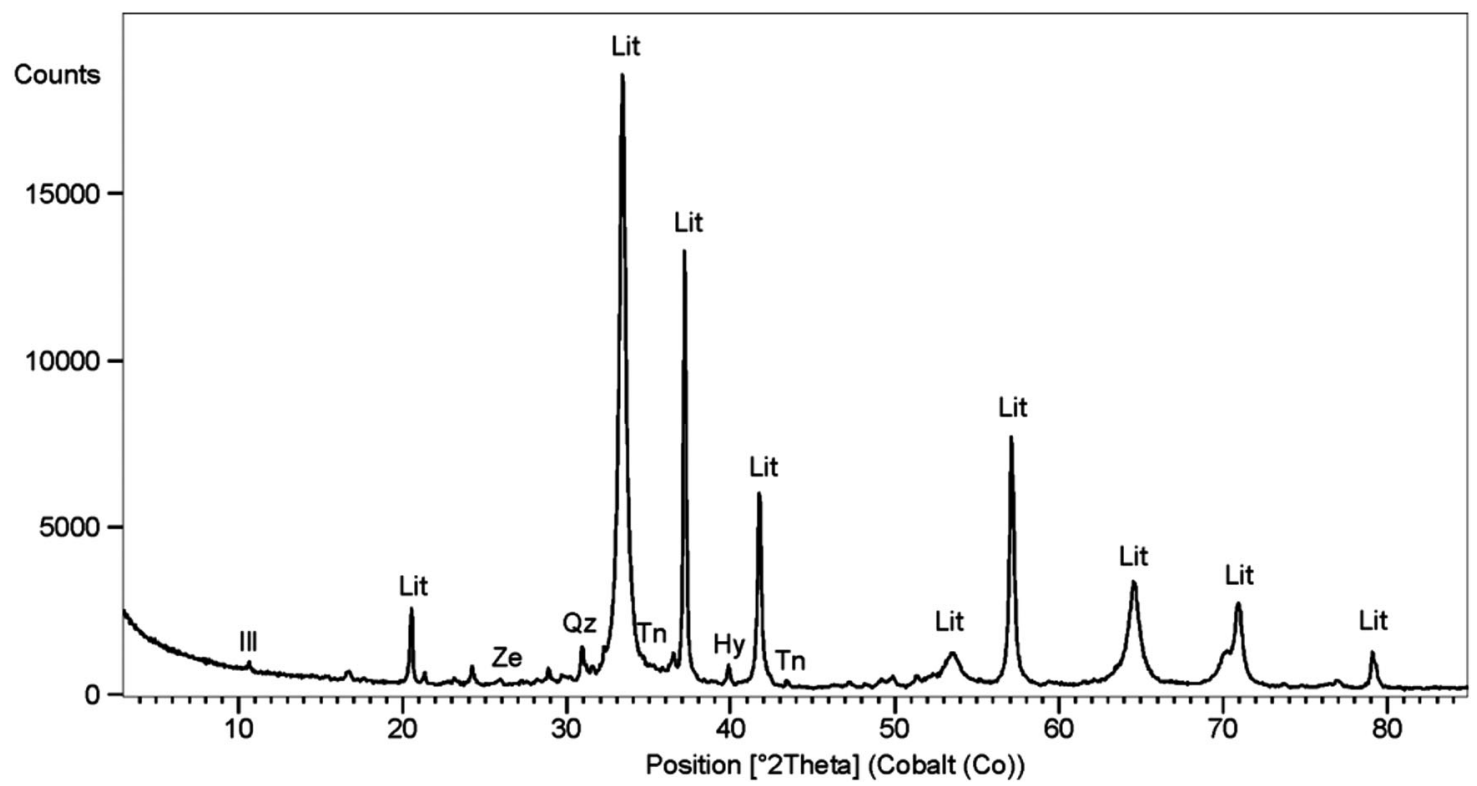

Figure 11. XRPD pattern of a small solid fragment of the bulb's casting core. Abreviations: Hy: hydrocerussite, Ill: illite/muscovite, Lit: litharge, Qz: quartz, Ze: zeolite, Tn: tennantite (L. Maritan). 
excised in the plastic ground. Then, the core was dried or gradually fired, and a $3 \mathrm{~mm}$ layer of wax was applied around the solid outlines of the figures to be openworked, together with the metal-supplying canals and those planned for the escape ducts of gas. Third, an outer shell or investment mould in clay was applied to the object. Fourth, the whole mould was dried and fired, evacuating the wax shell. Fifth, the copper alloy was poured into the objects creating a jacket with the openwork outlines planned for the figures. What was left, at this point, was to fix the shell inlays within the openwork outlines, to form solid animal figures at the same level of the copper alloy shell, eventually filling the object with molten lead.

Some steps of the process remain unclear. According to one theory, the copper jacket was filled with a bag full of sand, and the shell inlays were fixed to the inner sand filling with series of tiny wood spikes; then, the exterior of the mould was coated with a second outer mould that retained the shell inlays in the planned places. Finally, the sand was removed, and lead was poured inside, creating the animal figures and their shell spots at the same time. This reconstruction is supported by the presence, below the inlays, of small rectangular holes left by the hypothesised burnt supports. ${ }^{10}$ As an alternative, lead was cast at first, and then shell inlays were mechanically inserted digging on the lead surface with a chisel at a second time. The small rectangular holes in the sockets, in this light, would remain unexplained.

Another impressive bronze artefact was cast in Susiana, at the time of king Untaš-Napiriša (ca. 1340-1300 BC). Probably originally located in Chogha Zanbil / Dur-Untaš-Napiriša, but found in 1903 in the Acropolis of Susa, ${ }^{11}$ the $1750 \mathrm{~kg}$ bronze statue of queen Napir-Asu was produced with two different castings, one for the core (11\% tin bronze), one for the shell (1\% tin bronze). According to Tallon ${ }^{12}$, the core was produced before the shell, while Meyers ${ }^{13}$ convincingly argued that, as the melting point of the core copper alloy was lower that the alloy of the shell, the core casting could only have been poured in the shell.

Both the late $4^{\text {th }}$ millennium BC Shahi-Tump "Leopard" weight and the 14th century BC Susian statue of Napir-Asu follow finally similar production patterns: an external shell / jacket produced with an alloy melting at a higher temperature, in which was poured afterwards a different material core melting at a lower temperature in order to fill it (1: high temperature melting material
/ 2: low temperature melting material filling it). As it is about to be shown, the mid- $3^{\text {rd }}$ millennium BC Jiroft sceptre under discussion here present an opposite production pattern, with a lead core (low temperature melting material) on which was moulded a copper alloy shell (high temperature melting material), probably in order to evacuate the lead core (1: low temperature melting material / 2: high temperature melting material used to flow it out).

\section{Preliminary Hypothesis on the Manufacturing Sequence of the Sceptre}

The "Leopard weight" from Shahi-Tump and the Jiroft sceptre share a basic parent manufacturing process (a direct lost-wax casting process involving a leadbased core) and the insertion on the metal surfaces of geometric shell inlays of contrasting colours (white and red). But the chaine opératoire of the sceptre was probably different. It is summarised in Figure 12. According to what we presently know, the first step was to make a solid "meagre" model of the sceptre, made of lead (Figure 12, 1-5). Such lead core (presumably cast, in turn, by a lost wax process) was then covered by a layer of clay mixed with angular (crashed) pieces of quartz and feldspars (from a ground intrusive rock?) (Figure 12, 6). This second shell was then covered with an even, well-formed layer of wax (Figure 12, 7), on which all decorative details, including the shell mosaics, were attached (Figure 12, 8).

We suggest that the squares/lozenges in slight relief that envelop the sceptre were made by applying to the wax model the pre-formed, threefold wax strips in long intersecting spirals. These strips were gradually applied in intersecting spirals, departing from the base to join into the diamond-like top of the bulb.

The insertion of the shell inlays, as ingeniously envisaged for the "weight", presents peculiar technical problems. In not a few instances, the edges of the rectangular inlays of the crosses look displaced and overlapped to a variable extent by the bronze flow, their axes being slightly shifted from their planned orthogonal and level lay-out (Figure 13). This suggests that shell inlays were directly set in the wax model, to have them trapped in place while wax was replaced by the molten flow of copper/bronze. So, how could the inlays stay in place when wax did no longer keep the mosaics in place, and copper was flowing downwards?

\footnotetext{
${ }^{10}$ Mille et al., "Metallurgical Study," Figure 7.

${ }^{11}$ Lampre, "Statue de la reine Napir-Asou," 245-250.

${ }^{12}$ Tallon, "Statue of queen Napir-Asu,"132-135.

${ }^{13}$ Meyers, "The Casting Process of the Statue of Queen Napir-Asu in the Louvre," 11-18.
} 

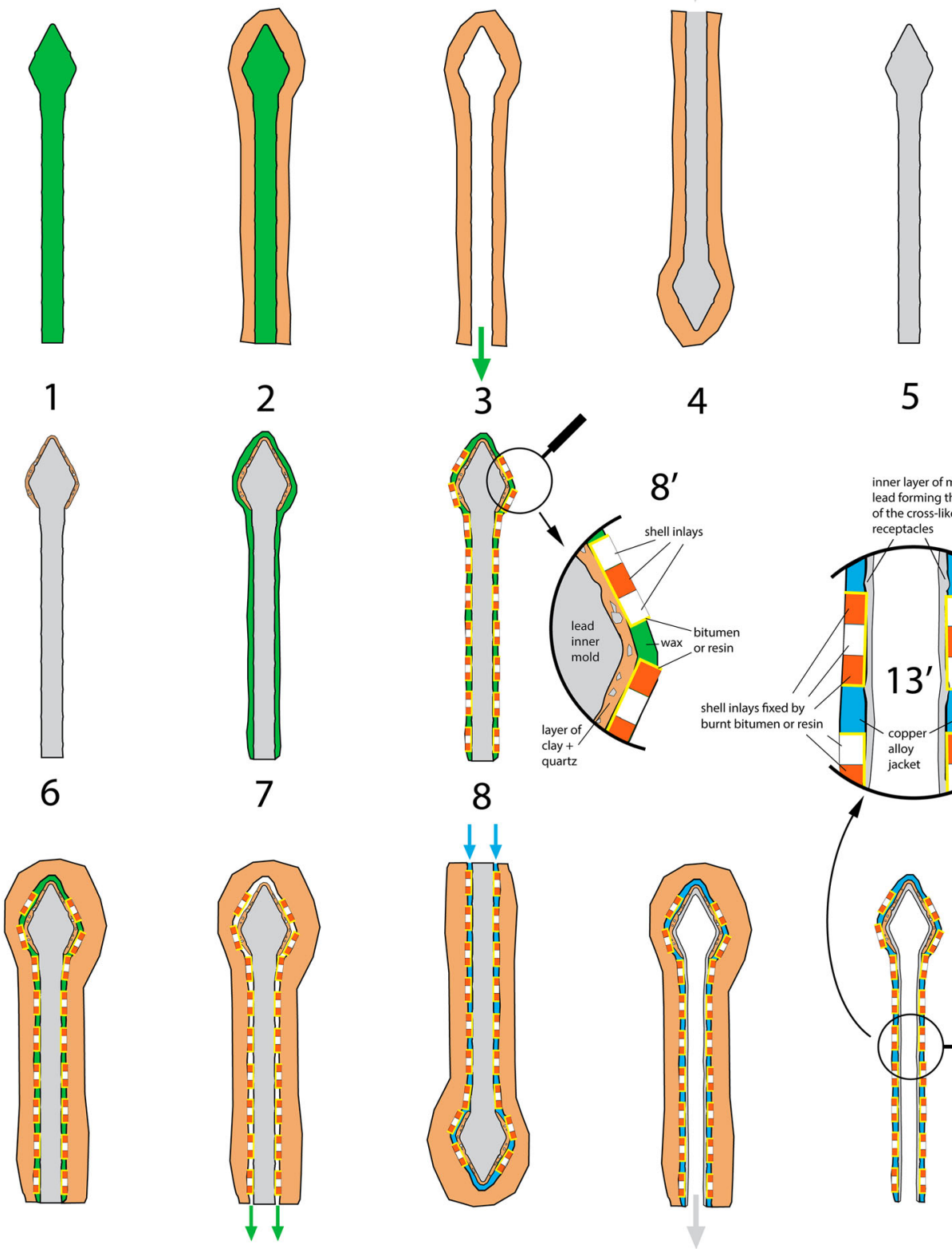

5
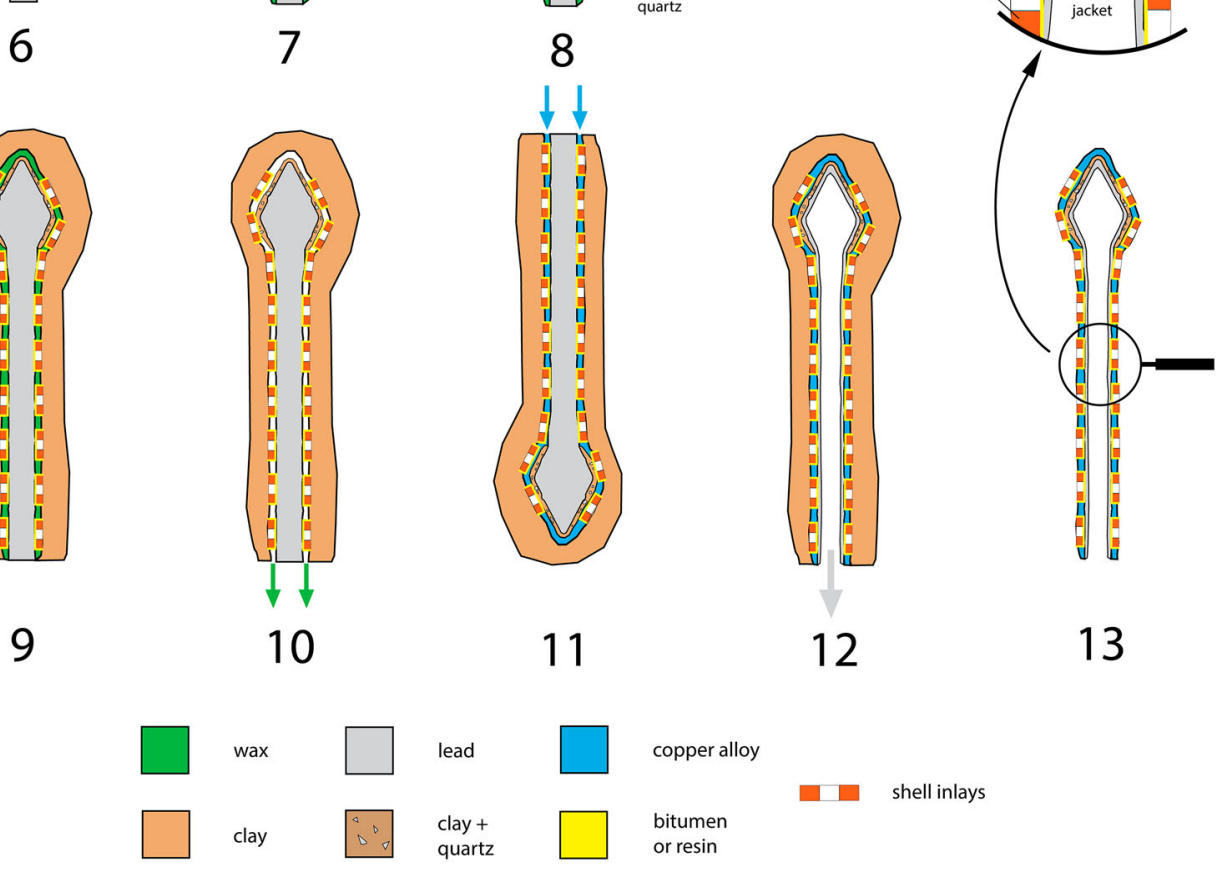

Figure 12. Graphic reconstruction of the multi-materials casting process of the Jiroft sceptre, discussed in detail in the text (F. Desset, M. Vidale).

A possible technical solution might have been to apply between the mosaics and the wax sockets a thin layer of an organic adhesive, with a melting point higher than that of wax (Figure 12, detail 8'). For example, generally speaking, wax melts at $\mathrm{ca} 65^{\circ} \mathrm{C}$, while the melting point of bitumen (asphalt) wavers from 54 to $173^{\circ} \mathrm{C} ;{ }^{14}$ vegetal resins may melt at much higher temperatures. ${ }^{15}$ Thus (in principle) it is possible that coppersmiths had placed

\footnotetext{
${ }^{14}$ ILO and WHO, "ICSC-0612 Asphalt," 2017.

${ }^{15}$ Yusuf, "Studies on Some Physicochemical Properties of the Plant Gum Exudates of Acacia senegal (Dakwara), Acacia sieberiana (Farar Kaya) and Acacia nilotica (Bagaruwa)," 10-17.
} 


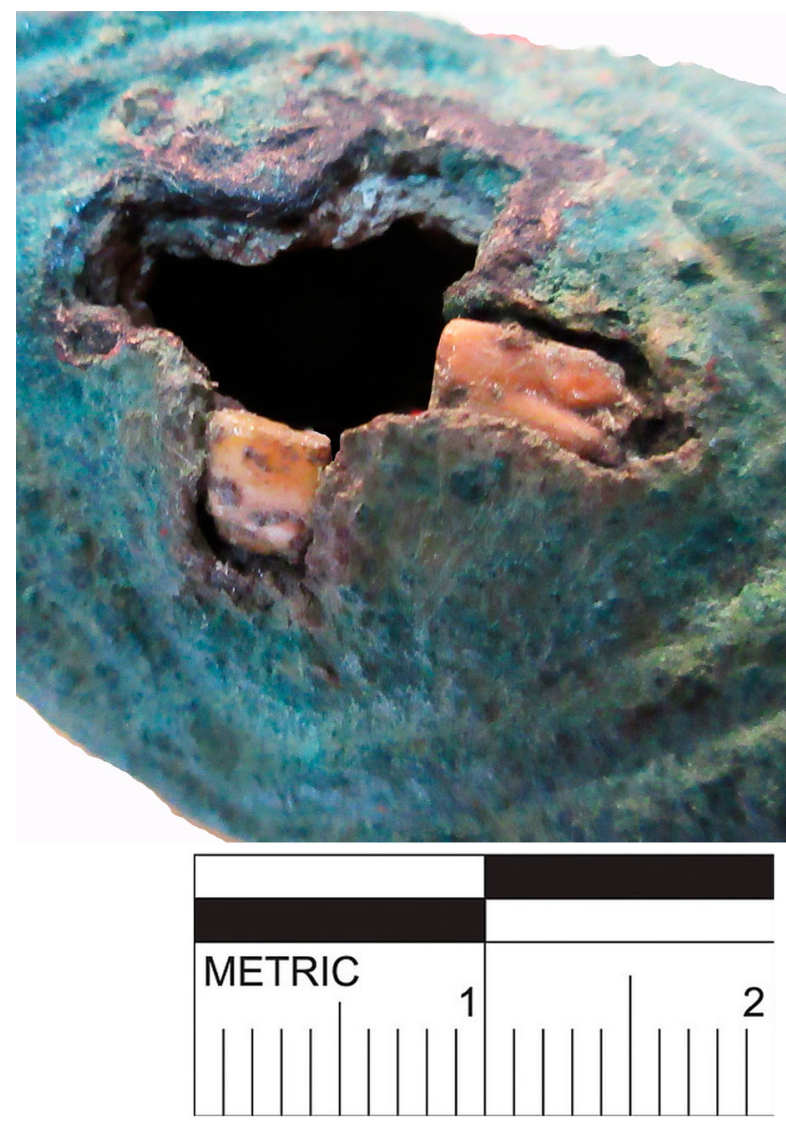

Figure 13. Detail of one of the cross-shaped receptacles, showing two of the original shell inlays displaced and partially engulfed by the copper/bronze flow (M. Vidale).

within the cross-like receptacles a thin layer of a heatresistant organic adhesive that could resist the melting temperatures of wax, but was later dissolved at the higher temperatures of casting. Perhaps the variable colours and alteration surfaces observed around and below the mosaic crosses are due to similar techniques. The detail of one of the cross-like receptacles (Figure 14) actually shows a continuous film of a black substance surviving between the inlays and the copper/bronze wall and above the lead background of the inner cavity of the handle, possibly a residue of such adhesive.

The melt, given the traces of tennantite within the inner jacket of the bulb, was likely a leaded arsenical bronze, the most common type of copper alloy in Middle Asia during the $3 \mathrm{rd}$ millennium $\mathrm{BC}^{16}$

We propose that when the mould was coated with an outer layer of clay (Figure 12, 9) and wax was rapidly evacuated (Figure 12, 10), an adhesive kept the shell mosaics in place, until the cavity between the casting core and the outer mould was filled by the bronze flow

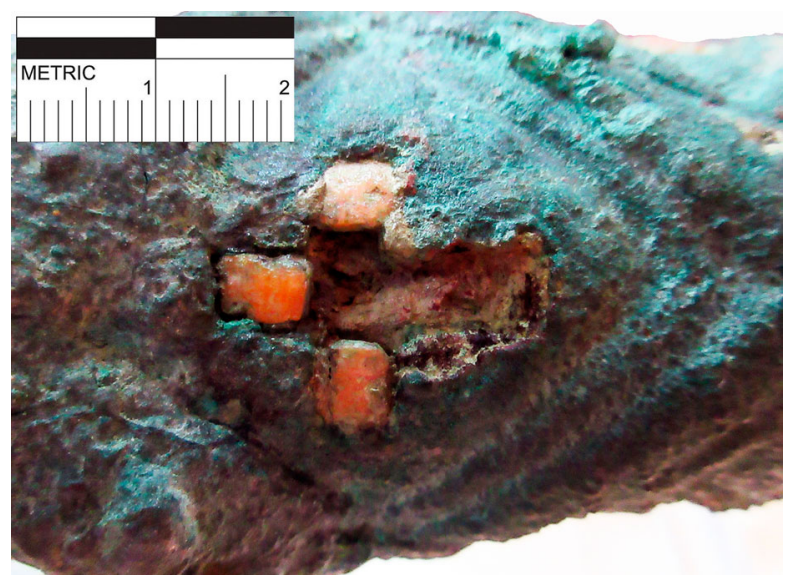

Figure 14. Detail of another cross-shaped receptacle, showing a film of a carbonised substance (possibly a heat-resistant adhesive) still supporting the inlays (M. Vidale).

(Figure 12,11). Along the inner wall of the bulb, the intermediate layer of clay and crushed rock temper was locally affected by a localised sintering process that gave birth to the neo-formed, high temperature phases detected by XRDP (see above, Figures 10(c,d) and 11). While the mould was gradually cooling, the lead core had melted and remained in such a state within a rather wide temperature range: ideally, between the ca. $1000^{\circ} \mathrm{C}$ of the melting temperature of most copper/bronze alloys, and the $327.5^{\circ} \mathrm{C}$ of lead (but even minor variations in the percentages of arsenic could considerably lower the melting point of the alloy). ${ }^{17}$ In this range, the mould could be set with the bulb up, letting the molten lead to flow downwards within the "tunnel" of the handle and exit through the basal hole (Figure 12, 12). As the sintered clay within the inner surface of the bulb would consolidate below ca. $950-900^{\circ} \mathrm{C}$, the lead mass originally contained in the bulb, as well as the residues of sintered clay and rock particles still adhering to the inner surface of the same part, could be removed as a flow, without breaking the copper/bronze shell.

The downpour of molten lead was possible as far as within the cavities of the sceptre there was an ongoing, simultaneous intake of oxygen. Some vents (of which, anyhow, there is no evidence) should have been placed on the bulb, but for letting air in while lead was escaping. This would explain the extensive formation on the inner bulb of bright red lead oxides, while hydrocerussite was later due to burial alteration. The skill of the smiths should have made possible the removal of the lead core, while leaving around the inner cavity of the handle, as far as possible, a lead coating, as a background meant

\footnotetext{
${ }^{16} \mathrm{Cfr}$, among others, Thornton and Roberts, "Introduction," 181-184; Helwing, "A Comparative View on Metallurgical Innovations in South-Western Asia," 161170; Weeks, "Iranian Metallurgy of the Fourth Millennium BC in Its Wider Technological And Cultural Context," 277-291.

${ }^{17}$ Hook et al, "The Early Production of Copper-Alloys in South-East Spain," 65-76.
} 

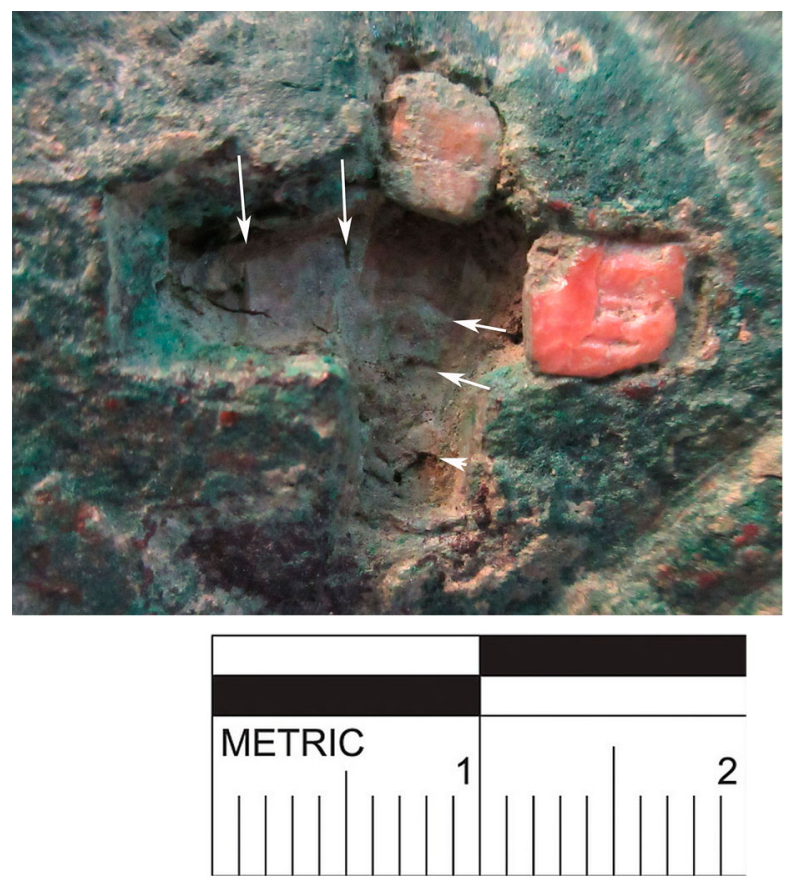

Figure 15. Detail of another cross-shaped receptacle; the white arrows show the marks left by a chisel with a curved end onto its lead background (M. Vidale).

to support from the interior the cross-mosaics (Figure 12, 13; and detail in 13').

The displacement of the inlays partially engulfed in the copper/bronze flow, well recognisable in Figure 13, shows that this complex technique might result in accidents, and required secondary adjustments. In other cases, in fact, the smiths took a lot of care for restoring the inlays to their planned cross-like patterns. In some of the receptacles from which the inlays had fell (or were removed), the lead background shows clear traces left by a sharp metal chisel (Figure 15). At least in another instance (Figure 16), we observed a continuous film of metal (possibly lead, Figure 16,1) evidently poured within the cavity to re-locate firmly the inlays in their planned setting. A bump visible in the same image (Figure 16, 2), partially covering two shell inlays, looks like a copper nail possibly inserted aside the shell mosaic.

\section{Conclusions}

The staff or sceptre discussed in this paper might have been recovered in a rich grave looted in the Jiroft area or, as an alternative, given the possible evidence of a

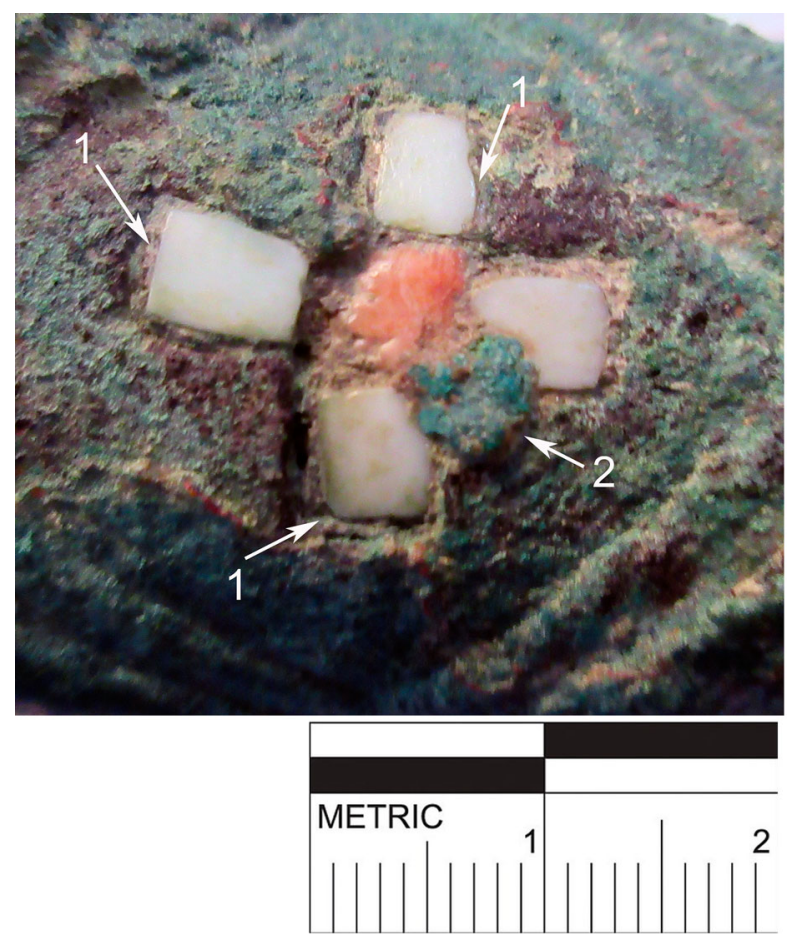

Figure 16. Detail of another cross-shaped receptacle, in which 1 points to a continuous metal film (probably lead), poured into the cavity for re-fixing the inlays in their correct positions; while 2 indicates a possible copper nail (given its distinctive colour, different from that of the sceptre) placed above the inlays (M. Vidale).

unfinished status, from an ancient hoard or workshop. Presumably, its date may be the same of the greatest majority of the looted objects so far published, around or shortly after the mid-third millennium BC. However, its intricate geometric style, based upon a combination of crosses of contrasting colours inscribed in squares or lozenges, does not exclude an earlier date, the late fourth millennium BC (as suggested by comparisons with some of the most common motives on the Namazga III pottery of southern Turkmenistan). ${ }^{18}$ Some other vessels in gold or silver known from southern central Asia (such as a famous gold cup belonging to the Fullol hoard), ${ }^{19}$ or coming from looted contexts ${ }^{20}$ present broadly similar geometric patterns, thus re-proposing the same uncertainty.

That the third millennium elites of southern central Asia and the neighbouring regions used as imposing symbols long staffs made of finely polished schist, micaschist, or chlorites across a vast region is very well known after the discovery of similar objects in the graves of Gonur (Murghab delta, southern Turkmenistan): for

\footnotetext{
${ }^{18}$ Masson, Altyn-Depe; Kircho, Korobkova and Masson, The Technical and Technological Potential of the Eneolithic Population of Altyn-Depe as the Basis of the Rise of an Early Urban Civilization.

${ }^{19}$ Cambon and Jarrige, Afghanistan. I Tesori Ritrovati, 100.

${ }^{20}$ Tosi and Lamberg-Karlovsky, "Pathways Across Eurasia," 347-376, catalogue 254, Figure 91b.
} 
example, in Graves M.077/1996, 0500/1999, and in the so-called "Dog Mausoleum". ${ }^{21}$ Its publication includes inventory of sites and contexts where similar items have been found. Locations, besides the 3rd millennium BC cemeteries of Margiana, are spread from the Kopet Dagh piedmont of southern Turkmenistan to the cenotaphs in the Quetta region of northern Baluchistan ${ }^{22}$ and Bactria. ${ }^{23}$ In the eastern Iranian Plateau, these stone staffs were found in the cemetery areas of Shah$\mathrm{dad}^{24}$ in the north-western corner of the Lut margin. Rather frequently, when information on the circumstances of the discovery are provided, such staffs were found in graves or cenotaphs.

An incised Bactrian silver vessel recently published shows a cortege of personages accompanying a prisoner in shackles headed by an individual wearing a ceremonial dress, who might hold a staff with what looks like a pointed bulb (Figure 17(a and b)). ${ }^{25}$

In fact, some of these sceptres, in Bactria and Margiana, had expanded finials or "bulbs" made of different materials (like stone, lead and copper) applied to the upper end (Figure $17(\mathrm{c}-\mathrm{e}))^{26} \mathrm{~A}$ finial in copper or bronze, applied to a schist-like rod, was found in the "Tomb of the Lamb" of Gonur (Figure 17(c-e)). ${ }^{27}$ Internally empty, its flattened globular bulb is decorated by a sequence of openwork crosses that remind of those appearing on the artefacts here discussed; on top, the object bears a multiple spiral or "endless knot", winding around five openings, in low relief. This sceptre's bronze finial provides the best, although partial, match with the Jiroft specimen. If these interpretations are correct, there is the possibility that the sceptre was defective, in the course of being restored, or left unfinished. If so, rather than in a grave, it could have been found in a hoard, or in the premises of a craft area - circumstances now impossible to verify.

The casting technology here outlined for the Jiroft sceptre needs to be further investigated once we will have had the permission to sample and analyze some of the parts and materials discussed in the reconstruction of Figure 12. However, it is already clear that a sequence of this kind involves a highly skilled know-how on the thermic behaviour and perfectly timed interaction among different materials like lead, clay, quartz, wax,

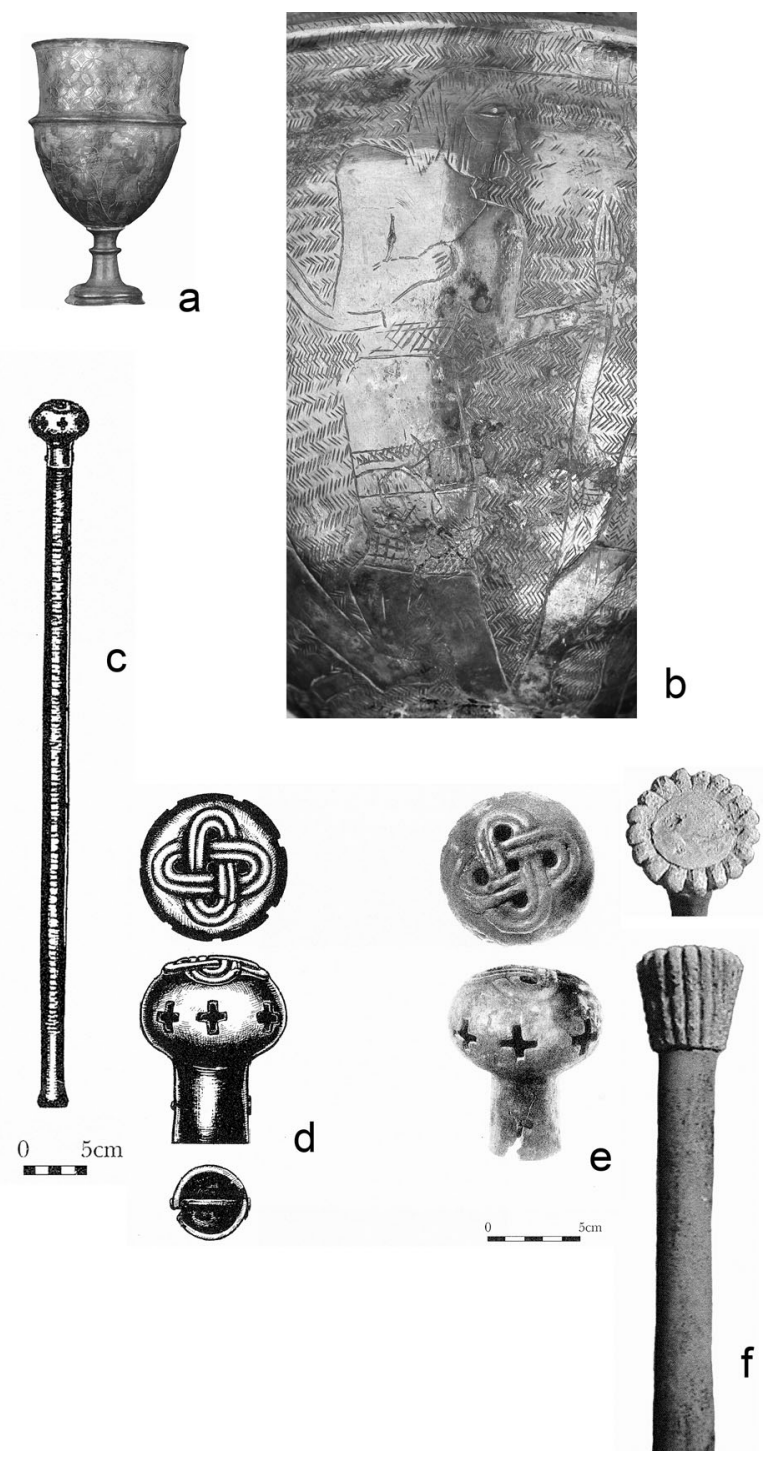

Figure 17. On top, $a$ and $b$ (not to scale): a Bactrian silver goblet, bearing a ceremonial scene, shows a personage who might carry a staff with a conical grooved finial. Below, c-e show some sceptres or "command sticks" (as they are sometimes called) from the graveyard of Gonur (Margiana, Turkmenistan): c and e (respectively, drawings and pictures) from the "Tomb of the Lamb" of Gonur North; f from Grave 0500/1999. References in the text.

probably a heat-resistant resin or bitumen, shell and a copper-arsenic alloy. The Leopard Weight from ShahiTump, the Jiroft sceptre and the Napir-Asu statue are as many examples of original, ambitious projects aimed

\footnotetext{
${ }^{21}$ Rossi-Osmida, "Considerations on the Necropolis at Gonur-Depe," 86-87, 90-91. Francfort and Rossi-Osmida, "The Dog Mausoleum," ibidem, 123, appears a paragraph entitled "A fragment of a Command Stick".

${ }^{22}$ Santoni, "Sibri and the South Cemetery of Mehrgarh," 52-60.

${ }^{23}$ Pottier, Matériel funéraire de la Bactriane méridionale de l'âge du bronze, 181, PI. V.

${ }^{24}$ Hakemi, Shahdad: Archaeological Excavations of a Bronze Age Center in Iran, 626.

${ }^{25}$ Vidale, Treasures from the Oxus. The Art and Civilization of Central Asia, 66-74. As far as we know, this is the only image in the wide iconographic repertory of southern Central Asia and the Eastern Iranian Plateau to possibly show the use of a similar staff in a ceremonial context (even if we cannot exclude that the personage in Figure 17, d is carrying a torch).

${ }^{26}$ Pottier, Matériel funéraire, PI. V-VIl; other specimens in Sarianidi and Dubova, Treasures of Ancient Margiana (Gadymy Margiananyň Genji-Hazinasy), 102.

${ }^{27}$ Sarianidi, Margiana and Protozoriastrism, Figure 135.
} 
at creating prestigious signs for the elites of their respective societies. Even though such large-scale bronze artworks share similar techniques of sequential and concentric castings in different materials, it is hard to ascribe them to a single metallurgical tradition.

Recent contributions ${ }^{28}$, in fact, underline that similar technical skills were deeply rooted in local middle-Asian traditions, apparently widely spread since the 5 th millennium $\mathrm{BC}$ with little or no gaps from the Hindukush piedmont to the Levant. To the obvious difficulties in reconstructing the chaîne opératoire of the sceptre, we must add that " ... the cultural interactions of people and groups within fourth-millennium BC Iran were complex and multidirectional and defy simple modelling". ${ }^{29}$ Actually, although the late fourth millennium BC "Leopard weight", the mid third millennium (?) Jiroft sceptre and the royal statue from Susa are somehow isolated in the socio-technical scenarios of their times, these creations confirm that in south-eastern Iran, at present “ ... research coverage is still extremely patchy... and nowhere have genuine workshop areas been documented in such a way as to make a comparison between the sites a meaningful undertaking" ${ }^{30}$ Admittedly, what we have is still very little, and it is with a sense of true wonder that we approach the study of similar artefacts. But in spite of the aspects of technical uniqueness emerging from this and other studies, the Jiroft sceptre confirms that we are certainly dealing with two millennia of unexpectedly skilled metallurgical practice, driven by unbroken and close links between craftsmen and their patrons, fully developed at least since the last centuries of the fourth millennium BC. ${ }^{31}$

\section{Acknowledgements}

The authors are very grateful to Ivana Angelini (University of Padova) for her important comments on a first draft of this paper.

\section{Disclosure Statement}

No potential conflict of interest was reported by the authors.

\section{Bibliography}

Besenval, Roland. "Between East and West: Kech-Makran (Pakistan) During Protohistory." In Cultural Relations between the Indus and the Iranian Plateau During the Third Millennium BCE, edited by Toshiki Osada, and Michael Witzel, 41-164. Cambridge, MA: Indus Project,
Institute for Humanities and Nature, June 7-8, 2008, Harvard University, Harvard Oriental Series Opera Minora Vol. 7, 2011.

Cambon, Pierre, and Jean François Jarrige, eds. Afghanistan. I Tesori Ritrovati. New York: Umberto Allemandi \& C., 2006. Desset, F., M. Vidale, N. Alidadi Solaimani, E. Battistella, and A. Daneshi. "A Grave of the Halil Rud Valley (Jiroft, Iran, ca. 2400-2200 BC): Stratigraphy, Taphonomy, Funerary Practices." Iranica Antiqua 52 (2017): 25-60.

Francfort, Henry-Paul, and Gabriele Rossi-Osmida. “The Dog Mausoleum." In Margiana Gonur-depe Necropolis 10 Years of Excavations by Ligabue Study and Research Centre, edited by Gabriele Rossi Osmida, 121-131. Trebaseleghe: Il Punto, 2002.

Frangipane, Marcella. “The Role of Metallurgy in Different Types of Early Hierarchical Society, in Mesopotamia and Eastern Anatolia." In Appropriating Innovations. Entangled Knowledge in Eurasia, 5000-1500 BCE, edited by Joseph Maran, and Philipp W. Stockhammer, 171-183. Oxford \& Philadelphia: Oxbow Books, 2017.

Hakemi, Ali. Shahdad: Archaeological Excavations of a Bronze Age Center in Iran. Rome: IsIAO, 1997.

Hansen, S. "Key Techniques in the Production of Metals in the 6th and 5th Millennia BCE: Prerequisites, Preconditions and Consequences, in Mesopotamia and Eastern Anatolia." In Appropriating Innovations. Entangled Knowledge in Eurasia, 5000-1500 BCE, edited by Joseph Maran, and Philipp W. Stockhammer, 136-148. Oxford \& Philadelphia: Oxbow Books, 2017.

Helwing, Barbara. "A Comparative View on Metallurgical Innovations in South-Western Asia: What Came First? in Mesopotamia and Eastern Anatolia." In Appropriating Innovations. Entangled Knowledge in Eurasia, 5000-1500 $B C E$, edited by Joseph Maran, and Philipp W. Stockhammer, 161-170. Oxford \& Philadelphia: Oxbow Books, 2017.

Hook, Duncan, Ian Freestone, Nigel D. Meeks, Paul T. Craddock, and Auxilio Moreno. "The Early Production of Copper-Alloys in South-East Spain.” In Archaeometry '90, edited by E. Pernicka, and Gunther A. Wagner, 65-76. Berlin: Birkhäuser Verlag Basel, 1991.

ILO and WHO. ICSC-0612 Asphalt. Accessed March 2018. http://www.inchem.org/documents/icsc/icsc/eics0612.htm.

Kircho, Ljuba B., Galina Fedorova Korobkova, and Vadim Mikhâ̂lovic Masson. The Technical and Technological Potential of the Eneolithic Population of Altyn-Depe as the Basis of the Rise of an Early Urban Civilization. The Institute for the History of Material Culture, Russian Academy of Sciences, Proceedings, vol. XXVIII. St Petersburg: European House, 2008.

Lampre, Georges. "Statue de la reine Napir-Asou." Mémoire de la Délégation en Perse 8 (1905): 245-250.

Madjidzadeh, Youssef. Jiroft. The Earliest Oriental Civilization. Tehran: Ministry of Culture and Islamic Guidance, Printing and Publishing Organization, Cultural Heritage Organization, 2003.

Masson, Vadim Mikhâ̂lovic. Altyn-Depe. Philadelphia: University Museum, University of Pennsylvania, 1991.

\footnotetext{
${ }^{28}$ Helwing, A Comparative View; and Hansen, Key Techniques.

${ }^{29}$ Weeks, Iranian Metallurgy; Thornton and Roberts, Introduction.

${ }^{30}$ Helwing, A Comparative View, 164.

${ }^{31}$ Frangipane, "The Role of Metallurgy in Different Types of Early Hierarchical Society in Mesopotamia and Eastern Anatolia," $171-183$.
} 
Meyers, Pieter. "The Casting Process of the Statue of Queen Napir-Asu in the Louvre." Journal of Roman Archaeology, supplementary series 39 (2000): 11-18.

Mille, Benoît, Roland Besenval, and David Bourgarit. "Early 'Lost-Wax-Casting' in Baluchistan (Pakistan): The 'Leopards-Weight' from Shahi-Tump." In Persiens Antike Pracht. Bergbau, Handwerk, Archäologie. Katalog der Ausstellung des Deutschen Bergbau-Museums Bochum, edited by Thomas Stöllner, Rainer Slotta, and Abdolrasool Vatandoust, 264-271. Bochum: Deutsches BergbauMuseum, 2004.

Mille, Benoît, David Bourgarit, and Ronald Besenval. "Metallurgical Study of the 'Leopards Weight' from ShahiTump (Pakistan)." In South Asian Archaeology 2001 vol. I: Prehistory, edited by Catherine Jarrige, and Vincent Lefevre, 237-244. Paris: Editions Recherche sur les Civilisations, 2005.

Moorey, Peter Roger Stuart. "The Chalcolithic Hoard from Nahal Mishmar, Israel, in Context." World Archaeology 20, no. 2 (2008): 171-189.

Piran, Sedigheh, and M. Hesari. Cultural Around Halil Roud and Jiroft, the Catalogue of Exhibition of Select Restituted Objects. Tehran: National Museum of Iran, 2005.

Piran, Sedigheh, and Youssef Madjidzadeh. Objects from the Jiroft Treasury. Soft Stone and Alabaster Objects (Recovered Collection) from the Halil River Basin. Tehran: National Museum of Iran, Pazineh, 2013.

Pottier, Marie-Hélène. Matériel funéraire de la Bactriane méridionale de l'âge du bronze. Paris: Éditions recherche sur les Civilizations, 1984.

Rossi-Osmida, Gabriele. "Considerations on the Necropolis at Gonur-Depe.” In Margiana Gonur-depe Necropolis 10 years of excavations by Ligabue Study and Research Centre, edited by Gabriele Rossi Osmida, 86--87. Trebaseleghe: Il Punto, 2002. 90-91.

Santoni, Marielle. "Sibri and the South Cemetery of Mehrgarh: Third Millennium Connections between the Northern Kachi Plain (Pakistan) and Central Asia." In South Asian Archaeology 1981, edited by Bridget
Allchin, 52-60. Cambridge: Cambridge University Press, 1984.

Sarianidi, Victor. Margiana and Protozoriastrism. Athens: Kapon, 1998.

Sarianidi, Wiktor, and Nadhezda Dubova. Treasures of Ancient Margiana (Gadymy Margiananyñ Genji-Hazinasy). Aşgabat: Türkmen döwlet neşirýat gullugy, 2003.

Tallon, Françoise. "Statue of Queen Napir-Asu." In The Royal City of Susa, Ancient Near Eastern Treasures in the Louvre, edited by Prudence O. Harper, Joan Aruz, and Françoise Tallon, 132-135. New York: The Metropolitan Museum of Art, 1992.

Thornton, Chris C., and Benjamin W. Roberts. "Introduction: The Beginnings of Metallurgy in Global Perspective." Journal of World Prehistory 22 (2009): 181-184.

Thoury, Mathieu, Benoît Mille, Tatiana Séverin-Fabiani, Luc Robbiola, Matthieu Réfrégiers M., Jean-Francois Jarrige, and Loïc Bertrand. "High Spatial DynamicsPhotoluminescence Imaging Reveals the Metallurgy of the Earliest Lost-Wax Cast Object." Nature Communications 7 (2016): 13356. doi:10.1038/ncomms13356 | www.nature. com/naturecommunications.

Tosi, Maurizio, and Carl C. Lamberg-Karlovsky. "Pathways Across Eurasia." In Art of the First Cities, edited by Joan Aruz, and Ronald Wallenfels, 347-376. New Haven and London: Yale University Press, 2003.

Vidale, Massimo. "Searching for Mythological Themes on the 'Jiroft' Chlorite Artefacts.” Iranica Antiqua 50 (2015): 15-58.

Vidale, Massimo. Treasures from the Oxus. The Art and Civilization of Central Asia. London: Tauris, 2017.

Weeks, Lloyd. "Iranian Metallurgy of the Fourth Millennium BC in its Wider Technological and Cultural Context." In Ancient Iran and its Neighbours. Local Developments and Long-Range Interactions in the Fourth Millennium BC, edited by Cameron A. Petrie, 277-291. Oxford and Oakville: Oxbow Books, 2013.

Yusuf, A. K. "Studies on Some Physicochemical Properties of the Plant Gum Exudates of Acacia senegal (Dakwara), Acacia sieberiana (Farar Kaya) and Acacia nilotica (Bagaruwa)." Journal of Research in National Development 9, no. 2 (December 2011): 10-17. 